\title{
ANALÝZA ROZHLEDOVÝCH POMĚRŮ NA PŘECHODECH PRO CHODCE
}

\section{ANALYSIS OF SIGHT CONDITIONS AT PEDESTRIAN CROSSINGS}

\author{
Lucie Kejvalová*,1, Hana Kobzová ${ }^{1}$
}

"kejvalova.1@fce.vutbr.cz

${ }^{1}$ Vysoké učení technické v Brně, Fakulta stavební, Ústav pozemních komunikací, Veveři 331/95, 60200 Brno, Česká republika

\begin{abstract}
Abstrakt
Předmětem práce je analýza návrhových parametrů pro rozhledové poměry na přechodech pro chodce. Stávající české normy začínají být vzhledem k vzrůstajícím požadavkům na zajištění bezpečnosti a ochrany účastníků silničního provozu, ochrany životního prostředí, snížení časové náročnosti při dopravě, a především k masivnímu rozvoji dopravy nevyhovující. V současné době se v platné české normě ČSN 736110 objevují požadavky na rozhledové poměry na přechodech pro chodce, které jsou matoucí s ohledem na jejich nejednoznačnost, vypovídající hodnotu nebo neproveditelnost. Článek je zaměřený na popis a zhodnocení současného stavu rozhledových trojúhelníků na přechodech pro chodce a na poukázání na nadbytečnost a duplicitu informací v normě, jejichž odstranění by přispělo k jejímu zpřehlednění.
\end{abstract}

\section{Klíčová slova}

Rozhledové trojúhelníky, návrhové parametry, přechod pro chodce

\begin{abstract}
The main focus of the paper is the analysis of design parameters for sight distance at pedestrian crossings. The current Czech standards are beginning to be unsatisfactory due to the growing requirements for ensuring the safety and protection of road users, reducing the time required for transport, and the massive development of transport. The valid Czech standard ČSN 736110 contains requirements for visibility conditions at the pedestrian crossing, which are confusing about their ambiguity, informative value, or impracticability. The article is focused on the description and evaluation of the current state of sight distance at pedestrian crossings and on pointing out the redundancy and duplication of information in the standard, the removal of which would contribute to its clarity.
\end{abstract}

Key words

Sight distance, design parameters, pedestrian crossing

\section{1 ÚVOD}

V době neustále nových intenzivnějších vědeckých poznatků a s tím souvisejících technických pokroků, které se promítají do všech oblastí, tedy i automobilového průmyslu, se zvyšují také nároky na provoz na pozemních komunikacích. V současné době stanovují požadavky na rozhledová pole a rozhledové trojúhelníky ČSN 736101 , ČSN 736102 a ČSN 736110 [1], [2], [3].

Článek navazuje na diplomovou práci Optimalizace rozhledových trojúhelníků v ČSN 736110 a jeho cílem je popsat a zhodnotit současný stav rozhledových trojúhelníků na přechodech pro chodce a dále navrhnout možné úpravy, které by vedly ke zlepšení rozhledových poměrů ve vybrané oblasti, zjednodušení konstrukce rozhledových trojúhelníků a odstranění nadbytečných a duplicitních informací v normě, což může mít pozitivní vliv na zvýšení bezpečnosti na přechodech pro chodce od rané fáze projektu.

Na problematiku zabývající se místy pro přecházení není v článku prostor, nicméně při jejich řešení se předpokládá vycházet ze stejných nebo obdobných principů jako v př́ípadě přechodů pro chodce. 


\section{POPIS SOUČASNÉHO STAVU}

V současné době se v platných předpisech, kterými se projektant při návrhu technického řešení řídí, objevuje nejednotnost, nejednoznačnost či dokonce kontradikce $\mathrm{v}$ definování rozhledových trojúhelníků na přechodech pro chodce.

Př́kladem může být rozlišitelnost přechodu pro chodce. Ta je definována v ČSN 736110 Projektování místních komunikací z roku 2006 v tabulce 17 (Obr. 1) a přestože není zřejmé, co přesně je danou rozlišitelností míněno nebo jakým způsobem se určila př́slušná hodnota délky rozlišitelnosti, je požadováno, aby se daná hodnota dodržela, a to především ve směrových a výškových obloucích [3].

Tabulka 17 - Nejmenši vzdálenosti pro rozlišitelnost přechodu a rozhledové poměry na přechodech pro chodce a na mistech pro přecházení

\begin{tabular}{|c|c|c|c|c|}
\hline & \multicolumn{3}{|c|}{ Dovolená rychlost } \\
\hline & & $50 \mathrm{~km} / \mathrm{h}$ & $40 \mathrm{~km} / \mathrm{h}$ & $30 \mathrm{~km} / \mathrm{h}$ \\
\hline \multicolumn{2}{|l|}{ rozlišitelnost přechodu } & $100 \mathrm{~m}$ & $60 \mathrm{~m}$ & $50 \mathrm{~m}$ \\
\hline \multicolumn{2}{|c|}{$\begin{array}{l}\text { rozhledová vzdálenost } \\
\text { na čekací plochy přechodu (pro řidiče) } \\
\text { a z čekacich ploch přechodu na jízdni pás (pro chodce) }\end{array}$} & $50 \mathrm{~m}$ & $35 \mathrm{~m}$ & $30 \mathrm{~m}$ \\
\hline \multicolumn{2}{|l|}{ rozhled pro zastavení } & $35 \mathrm{~m}$ & $25 \mathrm{~m}$ & $15 \mathrm{~m}$ \\
\hline \multirow[t]{2}{*}{$\begin{array}{l}\text { a, b = délka volného rozhledového pole } \\
\text { pro řidiče } \\
\text { ve směru k vyznačenému přechodu }\end{array}$} & $\begin{array}{l}\text { na čekaci plochu prechodu } \\
\text { na pravé straně komunikace } \\
\text { ve směru jizdy - a }\end{array}$ & $20 \mathrm{~m}$ & $15 \mathrm{~m}$ & $10 \mathrm{~m}$ \\
\hline & $\begin{array}{l}\text { na čekací plochu prechodu } \\
\text { na levé straně komunikace } \\
\text { ve směru jizdy - b }\end{array}$ & $15 \mathrm{~m}$ & $10 \mathrm{~m}$ & $5 \mathrm{~m}$ \\
\hline \multirow{2}{*}{$\begin{array}{l}\mathrm{c}, \mathrm{d} \text { = délka volného rozhledového pole } \\
\text { pro chodce } \\
\text { z mista pro přecházení }\end{array}$} & $\begin{array}{l}\text { na jízdní pás vlevo ve smèru } \\
\text { precházení - c }\end{array}$ & $12 \mathrm{~m}$ & $8 \mathrm{~m}$ & $5 \mathrm{~m}$ \\
\hline & $\begin{array}{l}\text { na jízdni pás vpravo ve směru } \\
\text { precházení - d }\end{array}$ & $6 \mathrm{~m}$ & $4 \mathrm{~m}$ & $3 \mathrm{~m}$ \\
\hline \multicolumn{5}{|c|}{ 1. délka rozhledového pole se měři od okraje prechodu; } \\
\hline \multicolumn{5}{|c|}{$\begin{array}{l}\text { 2. pokud je přechod/místo pro přecházeni doplněn vysazenou chodníkovou plochou a ta je předsazena préed okraj } \\
\text { jizdního pásu o více neż } 0,30 \mathrm{~m} \text { (nejvíce o } 0,70 \mathrm{~m} \text { ), pak se hodnoty délky rozhledového pole mohou zkrátit na } \\
\text { polovinu, ale na vyznačených přechodech na hodnotu } \geq 5,0 \mathrm{~m} \text { a na místech pro preecházení na hodnotu } \geq 3,0 \mathrm{~m} \text {; }\end{array}$} \\
\hline \multicolumn{5}{|c|}{$\begin{array}{l}\text { 3. chodec na vyznačeném přechodu musi být viditelný ve vzdálenosti } \geq 1,0 \text { m od obruby. Na místě pro přecházeni } \\
\text { se předpokládá, že chodec vyčkává těsně u bezpečnostního odstupu (viz obrázky } 54 \text { a } 55 \text { ); }\end{array}$} \\
\hline
\end{tabular}

Obr. 1 Ukázka tabulky 17 z normy ČSN 736110 [3].

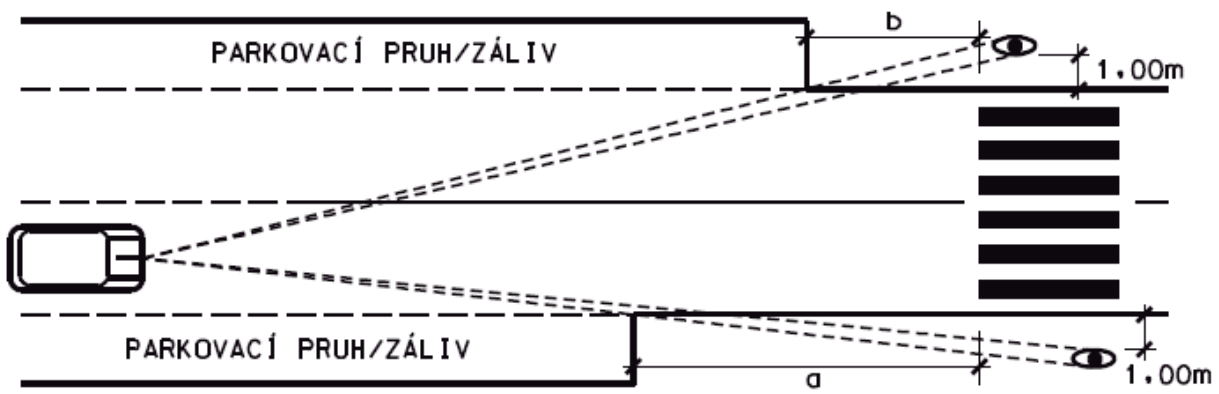

Obr. 2 Rozhled z vozidla na chodce u přechodu [3]. 


\section{METODIKA}

Článek se zabývá analýzou a zhodnocením návrhových prvků při konstrukci rozhledových trojúhelníků na přechodech pro chodce. Nejdříve bylo nutné vybrat a vyhledat veškeré dostupné informační zdroje týkající se dané problematiky. Poté byla provedena rešerše současných platných norem a předpisů. V další části byly analyzovány $\mathrm{z}$ výše zmíněných norem jednotlivé části návrhových parametrů potřebné pro konstrukci rozhledových trojúhelníků. V poslední části byly navrženy možné úpravy a optimalizace, které mohou vést ke zlepšení rozhledových poměrů ve vybraných oblastech, a to nejen z hlediska bezpečnosti, ale i komfortu a plynulosti silničního provozu.

\section{VÝSLEDKY ANALÝZY PŘEDPISŮ}

V této kapitole jsou prezentovány poznatky získané studiem návrhových prvků při konstrukci rozhledových trojúhelníků na přechodech pro chodce podle předmětné normy.

\section{Rozlišitelnost přechodu}

Vzdálenost, ve které si má řidič vozidla nejpozději uvědomit, že se před ním nachází přechod pro chodce a přizpůsobit dané situaci svou jízdu se označuje jako rozlišitelnost přechodu. V městské zástavbě bývá problematické požadovanou viditelnost dodržet, proto se $\mathrm{k}$ upozornění na přechod pro chodce uživá dopravní značka A11 Pozor, přechod pro chodce [4], [5].

\section{Rozhledová vzdálenost}

Rozhledová vzdálenost na čekací plochy přechodu (pro řidiče) a z čekacích ploch přechodu na jízdní pás (pro chodce) udává, v jaké minimální vzdálenosti od okraje přechodu musí mít řidič vozidla přehled o tom, jestli se chodci chystají přejít přechod pro chodce. Zároveň se jedná o rozhledovou vzdálenost pro chodce, která by jim měla pomoci rozhodnout se, zda vstupem do vozovky neohrozí sebe nebo ostatní účastníky silničního provozu [5].

Pokud do jednoho obrázku nakreslíme délky volného rozhledového pole pro řidiče na čekací plochy přechodu (hodnoty ,a“" a „,b“ z tabulky 17 (Obr. 1)), nejenže se neprotnou v témže bodě, ale neodpovídají ani hodnotě rozhledové vzdálenosti z téže tabulky, jak lze vidět na Obr. 3 [5].

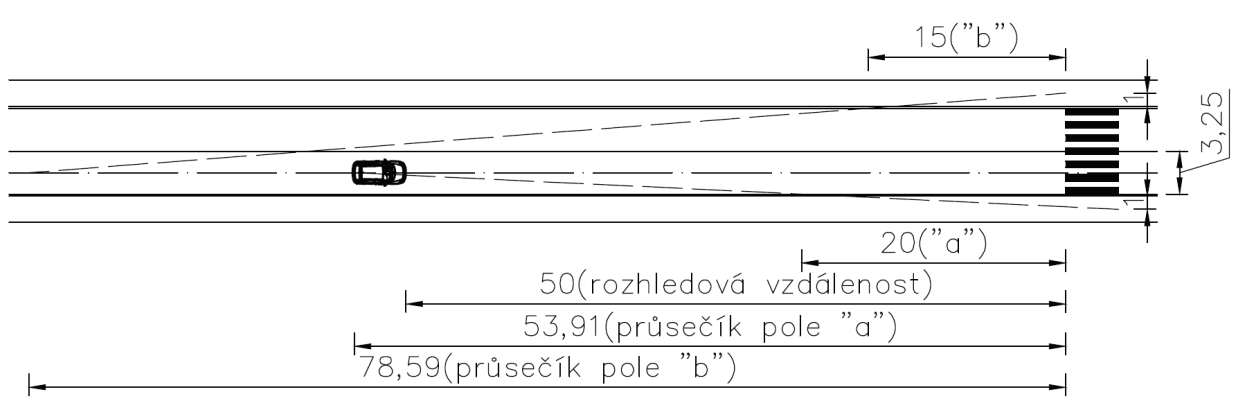

Obr. 3 Rozhledové vzdálenosti a délky volných rozhledových polí pro rychlost $50 \mathrm{~km} / \mathrm{h}$ [5].

Rozhledová vzdálenost je vypočtena podle vzorce z ČSN 736101 Projektování silnic a dálnic z roku 2018 pro reakční dobu $2 \mathrm{~s}$ a nulový podélný sklon, avšak pro rychlost $30 \mathrm{~km} / \mathrm{h}$ je zaokrouhlena o dalších $5 \mathrm{~m}$ nahoru [1].

\section{Rozhled pro zastavení}

Rozhled pro zastavení před přechodem pro chodce je vypočten podle vzorce z ČSN 736101 pro reakční dobu $1 \mathrm{~s}$ a nulový podélný sklon a odpovídá hodnotám $\mathrm{D}_{\mathrm{z}} \mathrm{z}$ tabulky 7 v normě ČSN 73 6110, avšak pro rychlost $30 \mathrm{~km} / \mathrm{h}$ je hodnota rozhledu pro zastavení před přechodem pro chodce oproti hodnotě $\mathrm{D}_{\mathrm{z}} \mathrm{z}$ tabulky 7 z ČSN 736110 podhodnocena (Tab. 1) [1], [3]. 
Tab. 1 - Délka rozhledu pro zastavení pro nulový podélný sklon v závislosti na reakční době a na rychlosti vypočtená podle ČSN 736101 Projektování silnic a dálnic z roku 2018 [5].

\begin{tabular}{cccc}
\hline \multirow{2}{*}{ Reakční doba [s] } & \multicolumn{4}{c}{ Dz při rychlosti $\mathbf{~} \mathbf{~ k m} / \mathbf{h}[\mathbf{m}]$} \\
& $\mathbf{5 0}$ & $\mathbf{4 0}$ & $\mathbf{3 0}$ \\
\hline $\mathbf{1}$ & 35 & 25 & 15 \\
$\mathbf{1 , 5}$ & 40 & 30 & 20 \\
$\mathbf{2}$ & 50 & 35 & 25 \\
$\mathbf{2 , 5}$ & 55 & 40 & 30 \\
$\mathbf{3}$ & 60 & 45 & 35 \\
\hline
\end{tabular}

\section{Vzdálenost chodce od obruby}

Podle ČSN 736110 musí být chodec viditelný ve vzdálenosti 1,0 m od obruby. Jedná se pouze o bezpečnostní rezervu, ve většině reálných případů dojde chodec k těsné hraně přechodu a až poté se rozhlíží [5].

Důležité je, aby řidič jedoucí ve vozidle měl přehled o dopravní situaci a aby měl dobrý výhled na přechod pro chodce. Tento výhled mu zajišt’uje rozhledová vzdálenost, ve které je již také započítaná bezpečnostní rezerva. Bezpečnostní rezervy jsou tedy uvažovány dvě. Jedna ve vzdálenosti chodce od obruby a druhá v rozhledové vzdálenosti řidiče [5].

\section{VARIANTY ŘEŠENÍ}

Při přecházení vozovky se kříží jízdní dráha vozidla s pěší dráhou chodce. S přihlédnutím k hmotnosti a rychlosti vozidla je však při střetu jednoznačná nevýhoda na straně chodce. Tvrzení, že chodec má na přechodu pro chodce absolutní přednost je však mylné. Řidiči vozidel sice musí umožnit chodci bezpečné přecházení, chodec ale nesmí vstupovat do vozovky bezprostředně před jedoucí vozidlo. Mnozí chodci si toto neuvědomují stejně tak, jako že osobní automobil zabrzdí v případě potřeby na kratší vzdálenost než několika tunový kamion s nákladem [6].

Vzhledem k nejasnosti výkladu tabulky 17 (Obr. 1), podle níž se navrhují přechody pro chodce, její nejednoznačnosti, zmatečnosti a nereálnosti splnění, nastává otázka, zda tabulku nezjednodušit [5].

Pro zajištění rozhledu je rozhodující pouze rozhledová vzdálenost, kterou je možno uvažovat shodnou s délkou rozhledu pro zastavení $\mathrm{D}_{z}$ při reakční době řidiče $2 \mathrm{~s}$. Rozlišitelnost přechodu a délky volných rozhledových polí "a" a "b" lze z nové tabulky vynechat [5].

Tab. 2 Rozhledové poměry na přechodech pro chodce [5].

\begin{tabular}{cccc}
\hline & \multicolumn{3}{c}{ Dovolená rychlost } \\
& $\mathbf{5 0} \mathbf{~ k m / h}$ & $\mathbf{4 0} \mathbf{~ k m / h}$ & $\mathbf{3 0} \mathbf{~ k m / h}$ \\
\hline rozhledová vzdálenost & $50 \mathrm{~m}$ & $35 \mathrm{~m}$ & $25 \mathrm{~m}$ \\
\hline
\end{tabular}

Z výše uvedených důvodů se nabízí tři varianty, jak nově kreslit rozhledové poměry na přechodech pro chodce podle Tab. 2.

\section{Varianta A}

Varianta A předpokládá, že chodec stojí v ose přechodu, a ne na jeho kraji. Většina chodců volí cestu nejbližší svému cíli a nedbá na obecné pravidlo držet se při jeho pravé straně. Pouze nepatrná část chodců zůstane na přechodě pro chodce během přecházení od začátku až do konce, zbytek chodců přechází zcela mimo přechod nebo začínají nebo končí mimo přechod [7].

Chodec musí být viditelný ve vzdálenosti 1 m od jízdního pruhu, stejně jako v nyní platné ČSN 736110 . Rozhledová vzdálenost se uvažuje od kraje přechodu k rozhledovému bodu řidiče dle Tab. 2 [5]. 

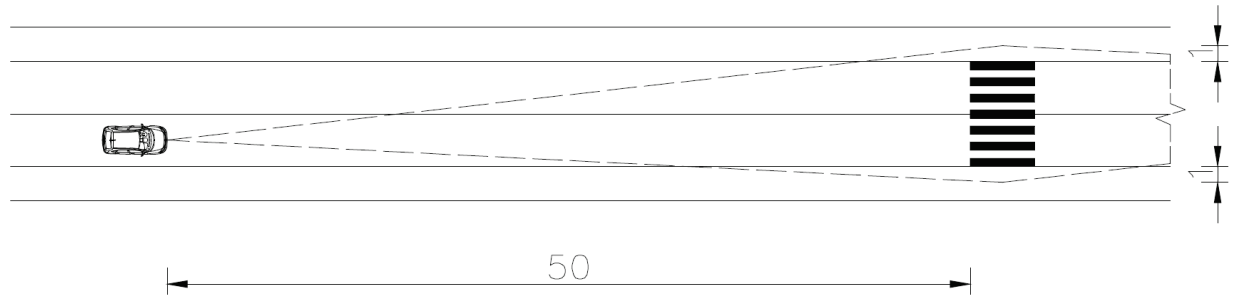

Obr. 4 Varianta A pro rychlost $50 \mathrm{~km} / \mathrm{h}[5]$.

\section{Varianta B}

Stejně jako ve variantě A se předpokládá pohyb chodců v ose přechodu, a ne na jeho kraji. Rozhledová vzdálenost se uvažuje od kraje přechodu k rozhledovému bodu řidiče dle Tab. 2 [5].

Zajištěn musí být výhled na chodce $0,5 \mathrm{~m}$ od jízdního pruhu. Vzdálenost $0,5 \mathrm{~m}$ reprezentuje bezpečnostní odstup od vozovky, za kterým už lze uvažovat bezpečně postaveného chodce. Na chodníku vyčkává jen 39 \% chodců, zbytek přecházejících vstupuje prímo do vozovky. Z tohoto důvodu lze uvažovat pouze s bezpečnostním odstupem chodce od vozovky, a to ve vzdálenosti 0,5 m [7].
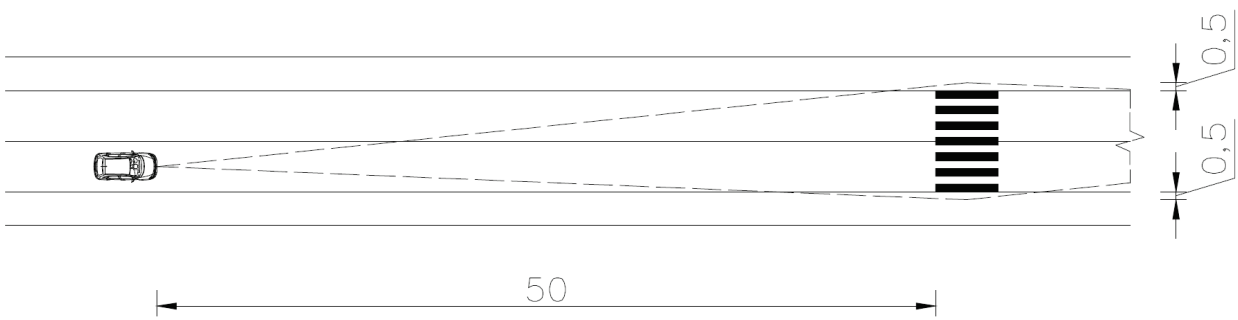

Obr. 5 Varianta B pro rychlost $50 \mathrm{~km} / \mathrm{h}[5]$

\section{Varianta C}

Varianta $C$ předpokládá pohyb chodců v celé šírce přechodu, proto musí být zajištěn výhled na chodce $0,5 \mathrm{~m}$ od jízdního pruhu nejen v ose přechodu, ale po celé jeho šířce. Rozhledová vzdálenost se uvažuje od kraje přechodu k rozhledovému bodu řidiče dle Tab. 2 [5].
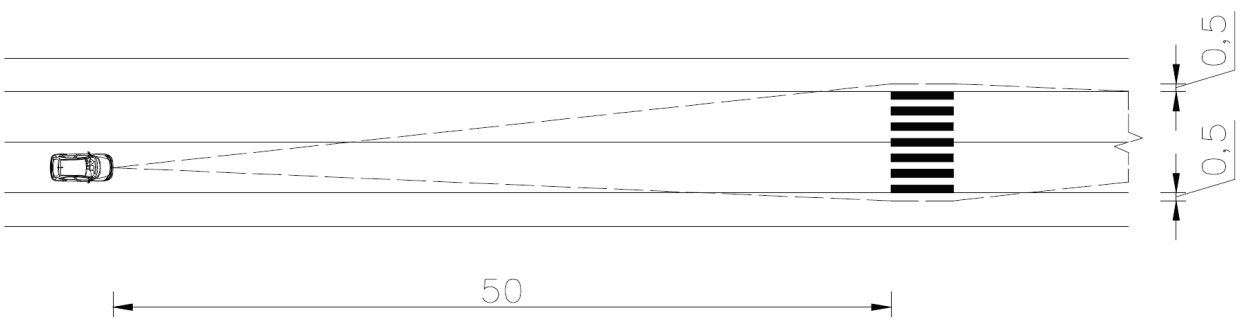

Obr. 6 Varianta C pro rychlost $50 \mathrm{~km} / \mathrm{h}[5]$.

\section{Zhodnocení variant}

Jako nejefektivnější a nejvíce odpovídající reálnému chování přecházejících se jeví varianta C, jelikož předpokládá pohyb chodců v celé šířce přechodu a rovněž uvažuje vzdálenost chodce od jízdního pruhu $0,5 \mathrm{~m}$. Tím je garantován výhled na chodce i na okraji přechodu. 


\section{ZÁVĚR}

Tento článek je zaměřen na problematiku přechodů pro chodce spojenou s konstrukcí rozhledových trojúhelníků podle ČSN 736110 Projektování místních komunikací z roku 2006, respektive se zajištěním rozhledu na přechodech pro chodce. Hlavním cílem bylo popsat stav současné platné normy, zhodnotit jej a navrhnout možnou optimalizaci, která by přispěla ke srozumitelnějšímu a jednoznačnému výkladu normy, což by vedlo k celkovému zjednodušení navrhování přechodů pro chodce a prověřování jejich rozhledových trojúhelníků.

Z výsledkủ rešerše vyplývá potřeba zjednodušit tabulku 17 (Obr. 1) a nahradit ji formou vycházející z Tab. 2 tohoto článku, ve které je opravena rozhledová vzdálenost na čekací plochy přechodu a z čekacích ploch přechodu na jízdní pás podle vzorce z ČSN 736101 na výpočet rozhledu pro zastavení, ve kterém se uvažuje reakční doba $2 \mathrm{~s}$ a nulový podélný sklon.

Dále byly navrženy tři varianty pro nový nákres rozhledových polí, z nichž se jako nejvýhodnější a nejvíce vypovídající jeví varianta $C$, ve které se předpokládá pohyb chodců $v$ celé širri přechodu pro chodce a ve které musí být zajištěn výhled na chodce 0,5 m od jízdního pruhu.

Zjišstěné poznatky jsou využivány při zpracování revize normy ČSN 736110.

\section{Poděkování}

Studie byla zpracována za finanční podpory VUT ze Specifického juniorského výzkumu FAST-J-21-7527.

\section{Použité zdroje}

[1] ČSN 736101 Projektování silnic a dálnic. Praha: Úřad pro technickou normalizaci, metrologii a státní zkušebnictví, 2018.

[2] ČSN 736102 Projektování křižovatek na pozemních komunikacích. Ed.2. Praha: Úřad pro technickou normalizaci, metrologii a státní zkušebnictví, 2012.

[3] ČSN 736110 Projektování místních komunikací. Praha: Český normalizační institut, 2006.

[4] TP 65 Zásady pro dopravní značení na pozemních komunikacích. Ministerstvo dopravy odbor pozemních komunikací, 2013.

[5] KEJVALOVÁ, Lucie. Optimalizace rozhledových trojúhelníků v ČSN 73 6110. Brno, 2021, 52 s., 5 s. př́l. Diplomová práce. Vysoké učení technické v Brně, Fakulta stavební, Ústav pozemních komunikací. Vedoucí práce Ing. Michal Radimský, Ph.D.

[6] Přecházení vozovky. BESIP [online]. 2017. Dostupné z: https://www.ibesip.cz/Tematickestranky/Aktivni-pohyb-v-silnicnim-provozu/Pesky/Prechazeni-vozovky

[7] POÓ, Fernando Martín, Ruben Daniel LEDESMA a Roberto TRUJILLO. Pedestrian crossing behavior, an observational study in the city of Ushuaia, Argentina. Traffic Injury Prevention [online]. 2018, 19(3), 305-310. ISSN 1538-9588. Dostupné z: doi:10.1080/15389588.2017.1391380 